Emir. J. Agric. Sci. 2005. 17 (2): 14-22

http://www.cfa.uaeu.ac.ae/Research/EJAS.htm

\title{
Growth performance, feed utilization, survival and body composition of rabbitfish Siganus canaliculatus raised at two different stocking densities in sea net cages
}

\author{
O. M. Yousif, K. Kumar and A. A. Ali
}

Fish and Shrimp Farming Project - Abu Al Abyad, Abu Dhabi, P.O. Box 372, United Arab Emirates

\begin{abstract}
Absract: Over a period of 213-day, the effect of two stocking densities (8 and $12 \mathrm{fish} / \mathrm{m}^{3}$ ) on the performance of the rabbitfish, Siganus canaliculatus $(3.38 \mathrm{~g} \pm 0.14)$ in floating cage nets was tested. The results of the study revealed no differences $(p<0.05)$ in the growth performance and survival of the two groups. Comparatively, the fish group under the higher stocking density (12 fish $/ \mathrm{m}^{3}$ ) exhibited a lower survival rate. The values of feed intake, feed utilization efficiency and final body composition for both treatments did not differ significantly $(\mathrm{p}<0.05)$. In conclusion, the study suggested the possibility of applying higher stocking density in commercial rabbitfish farming. However, more studies are needed on the effects of high stocking densities on fish survival.
\end{abstract}

Key Words: Siganus canaliculatus, sea cage nets, stocking density, growth performance, feed utilization.

\section{نم و، التتخ علم الهل، الحيالنية ومحتوى النبيحة لأسمك الصالفي

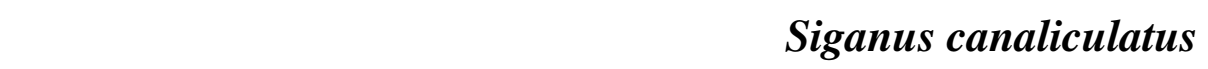 عمرمحمد يوسف، كربشنا كومار و عبد العتاح عبد الرحمن علي مشروع تربية الأسمك و الرويلن - أبو الأبيض -صب. 372 - أبولب الإمارل العربية المتحة

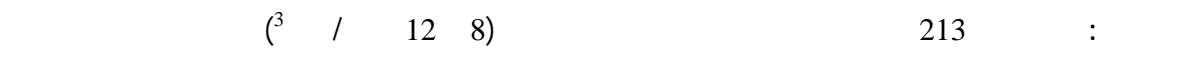

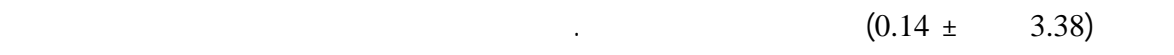

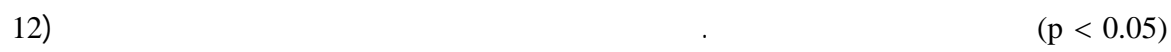

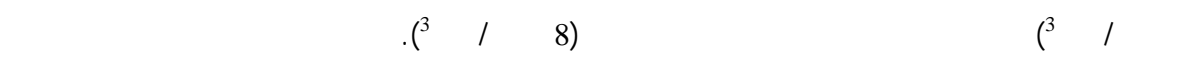

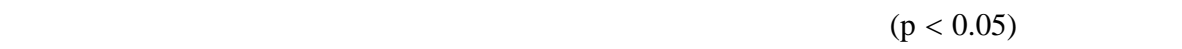

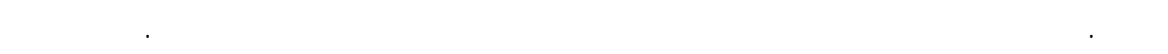 الدرلمة بمزيدمن الدرلسات لمعرفة تأثير الكثافلت العالية على حيلتية هذه الأسمك.

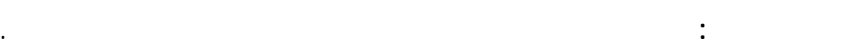

\section{Introduction}

The siganids are herbivourous marine fishes which inhibit rocky and weedy areas of the Indo Pacific area (Al-Abdessalaam, 1995; MAF, 2003). Naturally the fish browse on fleshy green algae and benthic plants. Both the juveniles and adults are primarily diurnal feeders, feeding almost continuously during the daytime
(Armando et al., 1999). The fact that the fish possess most of the desirable characteristics for aquaculture, several species have been tried in many countries for this purpose (Horstmann, 1975; Lichatowich et al., 1984; Parazo, 1990; Tacon et al., 1990; Yousif et al., 1996).

In the United Arab Emirates (UAE), the siganids, which are represented by Siganus canaliculatus 
and $S$. javus, enjoy a high and sustained demand in the country and the commercial size of rabbitfish accepted by the local consumers is 150 g (Anwahi et al., 1986). However, there is substantial gap between supply and demand. As a result, the retail prices of the fish sometimes reach as high as 20 dirham/kg (1 US $\$=3.68$ dirham). This gap was expected long time ago to be filled by the development of farmed siganids. (MAF, 1984). The successful hatchery production of rabbitfish, $S$. canaliculatus, in UAE has encouraged the development of plans for economically viable culture methods. Production trials of cultured rabbitfish started as early 1980s and continued since then (Anwahi et al., 1986; Yousif et al., 1996). At present there is an upsurge of interest among fishermen in small-scale cage culture (MRRC, 1995). Despite all these efforts and interest no advances are yet being made on their commercial culture and many aspects of their performance in different grow-out facilities remained unsolved. The paucity of suitable coastal land areas in UAE for fish farming makes cage culture an attractive option. Therefore, efforts should concentrate on the potential of cages in producing commercial crops of siganids. One of the main factors determining the economic feasibility of an aquaculture organism is the maximum stocking density that can be maintained without substantial reduction in growth rate. Higher stocking densities, beyond the optimum levels, may lead to reduction of growth rate, increase of feed conversion ratio and lowering of survival rate (Bjornsson, 1994; Yousif, 2002). However, there is no information on the performance of siganids in cages in UAE. Therefore, the current study was conducted to investigate the growth performance, feed utilization, survival, and body composition of rabbitfish, Siganus canaliculatus subjected to two different stocking densities in sea cage nets.

\section{Materials and Methods}

Fish and experimental procedure

Hatchery bred rabbitfish fingerlings of $3.38 \mathrm{~g} \pm 0.14$ (mean \pm s.d.) average body weight and $6.31 \mathrm{~cm}$ \pm 0.014 (mean \pm s.d.) in length were randomly distributed in four $5 \times 5 \times 2.5$ $\mathrm{m}^{3}$ (55 $\mathrm{m}^{3}$ water volume) floating cage nets with $20 \mathrm{~mm}$ square mesh nylon attached to a square steel pipe frames which were connected to the shore with a gangway. All cages were shaded from direct sunlight by green sheets. The steel pipe frames were floated by a $1 \times 0.5 \times 0.4 \mathrm{~m}^{3}$ styrofoam buoys in one of the dredged channels of $\mathrm{Abu} \mathrm{Al}$ Abyad Island, Abu Dhabi Emirate. The channel is $8 \mathrm{~m}$ deep with a good tidal water exchange rate. Two stocking densities of $8 \mathrm{fish} / \mathrm{m}^{3}$ and $12 \mathrm{fish} / \mathrm{m}^{3}$ were tested on duplicate group for 213 days (May to December 2001). The water quality parameters (water temperature, salinity, dissolved oxygen, transparency, and $\mathrm{pH}$ ) were measured every day inside the cage at a depth of $2.2 \mathrm{~m}$.

Commercial ARASCO (Saudi Arabia) sinking feed (52\% crude protein, $10 \%$ crude fat and $0.8 \%$ crude fiber) was hand fed to the fish three times a day. To avoid the loss of feed, a $1 \times 1 \mathrm{~m}^{2}$ feeding tray was hung in the water column about $1 \mathrm{~m}$ above the cage bottom. Each feeding tray was checked for remaining feed prior to the subsequent feed ration. Initially the fish were served a $1.2 \mathrm{~mm}$ particle size pellets at a rate of $7 \%$ body weight, 6 days a week, in the first month then replaced by $2 \mathrm{~mm}$ pellets, at $3 \%$ body weight, during the following 4 months 
and finally shifted to $4 \mathrm{~mm}$ pellets, at 2 $\%$ body weight, in the remaining two months. At monthly intervals, 50 fish were randomly sampled from each cage net, bulk weighed (in grams, g), individually measured (in centimeters, $\mathrm{cm}$ ) and the daily amount of feed was adjusted accordingly.

At the initiation and end of the study, fish samples from each cage were retained and kept frozen at -18 ${ }^{\circ} \mathrm{C}$ in sealed plastic bags for subsequent carcass analysis. Fish were first oven dried at $105^{\circ} \mathrm{C}$ for 24 hours to constant weight and then ground to homogenous powder using a kitchen blender. Fish carcass samples were analyzed in triplicate by standard methods AOAC (1984) for moisture, crude protein, crude lipid and ash.

Analytical procedure

Fish performance was evaluated in terms of percent survival, weight gain (g), specific growth rate (SGR $\% /$ day) and condition factor (K\%). The feed utilization efficiency was calculated in terms of feed conversion ratio (FCR), protein efficiency ratio (PER) protein retention efficiency (PRE \%) and energy retention efficiency (ERE \%) as follows:

Survival rate $(\%)=100$ [(final number of fish) - (initial number of fish) / (initial number of fish)]

Wt. Gain (g) = (final body wt -initial body wt.)

SGR (\%/day) $=100\left[\left(\log _{\mathrm{e}}\right.\right.$ final body

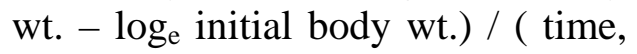
days)]

$\mathrm{K}(\%)=100$ (final body weight, g) / (final body length, $\mathrm{cm})^{3}$

FCR = [feed fed (dry wt., g)] / [fish wt. gain (fresh wt., g)]

PRE $(\%)=100$ [(final body protein, g) - (initial body protein, g) / (protein intake, g)]
ERE (\%) =100 [(final body energy, kJ)

- (initial body energy, kJ) / (energy intake, kJ)]

All data were subjected to statistical analysis using General Linear Models Procedures (SAS 1991).

\section{Results}

During the grow-out period water temperature ranged between $29^{\circ} \mathrm{C}$ and $33{ }^{\circ} \mathrm{C}$ and salinity ranged between 50 ppt and 53 ppt. A peak of $35{ }^{\circ} \mathrm{C}$ for temperature and $55 \mathrm{ppt}$ for salinity was recorded during July and August. The dissolved oxygen, transparency, and $\mathrm{pH}$ at the bottom of the cage net ranged during the culture season between 4.7 and 6.0 ppm; 210 and 220 $\mathrm{cm} ; 8.0$ and 8.57, respectively. All these ranges were considered as ideal levels for fish well-being in floating cages (Beveridge, 1996).

Growth performance of $S$. canaliculatus subjected to the two different stocking densities in cage nets is shown in Table 1. All growth parameters tested for both treatments showed an increase but did not differ significantly $(p<0.05)$. The final body weights attained within a period of 213 days for treatments 1 (8 fish $/ \mathrm{m}^{3}$ ) and 2 (12 fish $/ \mathrm{m}^{3}$ ) were $180.75 \mathrm{~g}$ and 184.75 g, respectively. The weight gain achieved was 177.39 and $181.35 \mathrm{~g}$ for treatments 1 and 2, respectively (figure $1)$. The values obtained for specific growth rate (SGR \%/day) and condition factor were almost the same for both treatments. The final survival rates for treatments 1 and 2 were 83.50 and $\quad 78.50 \%$, respectively. Comparatively, the fish under the higher stocking density (12 fish $/ \mathrm{m}^{3}$ ) exhibited a lower survival rate. 
O. M. Yousif et al.

Table 1. Growth performance and condition factor of $S$. canaliculatus stocked at two different densities in floating cage nets.

\begin{tabular}{lrr}
\hline & \multicolumn{2}{c}{ Treatment } \\
\cline { 2 - 3 } & \multicolumn{1}{c}{$\mathbf{1}$} & \multicolumn{1}{c}{$\mathbf{2}$} \\
\hline Initial weight (g) & $3.36 \pm 0.000$ & $3.36 \pm 0.000$ \\
Final weight (g) & $180.75 \pm 9.950$ & $184.75 \pm 1.950$ \\
Initial length (cm) & $6.31 \pm 0.010$ & $6.31 \pm 0.005$ \\
Final length (cm) & $21.69 \pm 0.295$ & $21.75 \pm 0.370$ \\
Survival (\%) & $83.50 \pm 2.500$ & $78.50 \pm 3.500$ \\
Weight gain (g) & $177.39 \pm 9.950$ & $181.35 \pm 1.950$ \\
SGR (\%/day) & $1.87 \pm 0.030$ & $1.88 \pm 0.005$ \\
Condition factor (\%) & $1.79 \pm 0.025$ & $1.80 \pm 0.075$ \\
\hline
\end{tabular}

Values are mean \pm SEM of two replicates. There were no significant differences between treatments $(p<0.05)$.

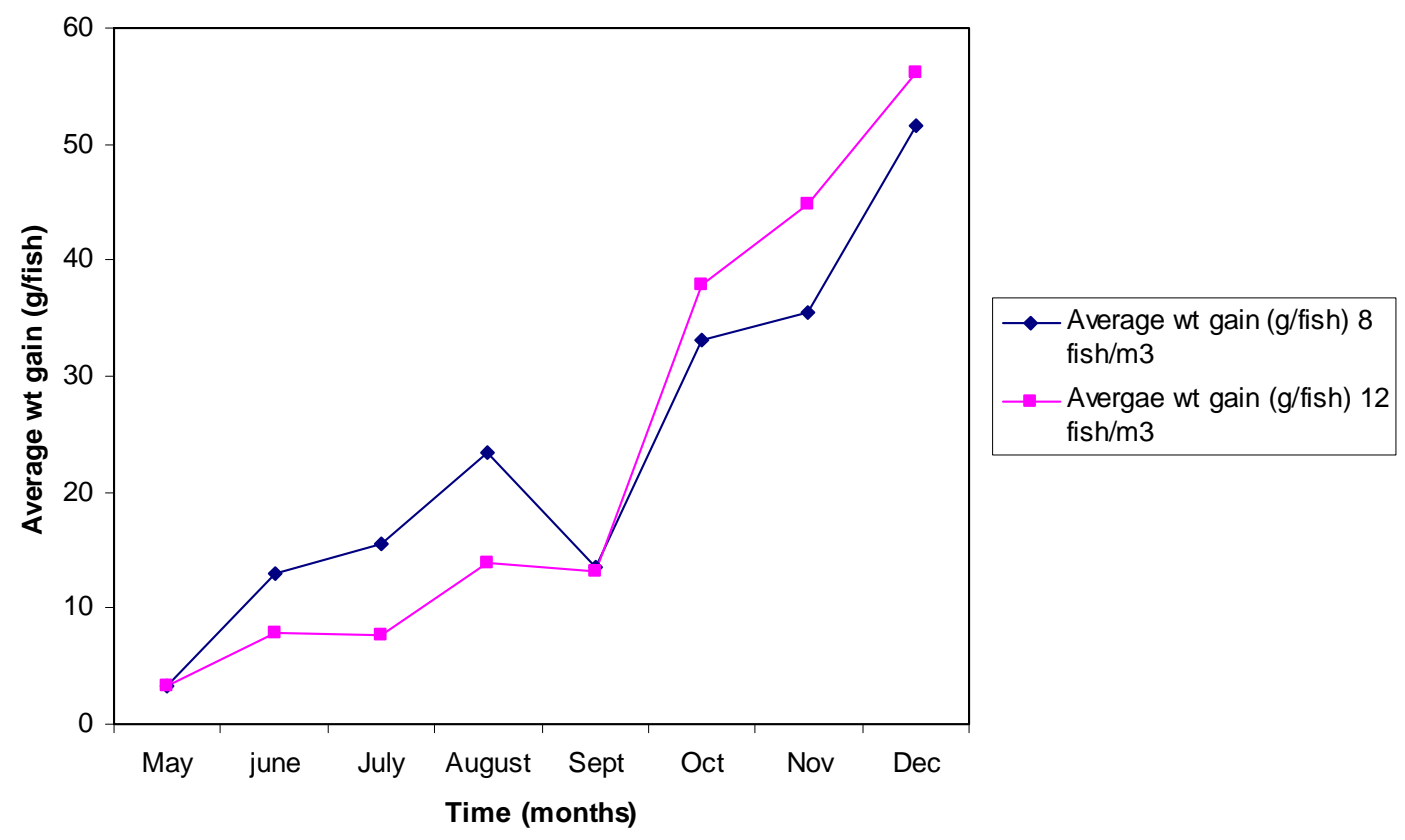

Figure 1. Weight gain of $S$. canaliculatus raised at different stocking densities in sea net cages.

Though the values of feed intake and feed utilization efficiency did not differ significantly $(\mathrm{p}<0.05)$ for both stocking densities (Table 2), the values of feed conversion ratio, protein efficiency ratio, protein retention efficiency and energy retention efficiency obtained for treatment 2 were slightly better than those for treatment 1. 
Emir. J. Agric. Sci. 2005. 17 (2): 14-22

http://www.cfa.uaeu.ac.ae/Research/EJAS.htm

Table 2. Feed intake and feed utilization efficiency of $S$. canaliculatus stocked at two different densities in floating cage nets.

\begin{tabular}{lrr}
\hline & \multicolumn{3}{c}{ Treatment } \\
\cline { 2 - 4 } & \multicolumn{1}{c}{1} & \multicolumn{1}{c}{2} \\
\hline Feed intake $(\mathrm{g})$ & $310.00 \pm 10.000$ & $260.00 \pm 10.000$ \\
FCR & $1.74 \pm 0.045$ & $1.43 \pm 0.070$ \\
PER & $1.10 \pm 0.025$ & $1.35 \pm 0.065$ \\
PRE (\%) & $65.13 \pm 1.490$ & $82.79 \pm 3.360$ \\
ERE (\%) & $7.42 \pm 0.780$ & $8.48 \pm 0.450$ \\
\hline
\end{tabular}

Values are mean \pm SEM of two replicates. There were no significant differences between treatments $(\mathrm{p}<0.05)$.

The final body composition showed no significant difference $(\mathrm{p}<$ lipid, ash and energy content between 0.05 ) in moisture, crude protein, crude the two experimental groups (Table 3).

Table 3. Carcass composition and energy content of $S$. canaliculatus (\% wet weight) stocked at two different densities in floating cage nets.

\begin{tabular}{lrrr}
\hline & Initial & \multicolumn{2}{c}{ Treatment } \\
\cline { 2 - 4 } & \multicolumn{3}{c}{1} \\
\hline Moisture & 74.45 & $67.18 \pm 0.275$ & $68.48 \pm 0.275$ \\
Crude protein & 16.30 & $19.49 \pm 2.725$ & $19.44 \pm 0.525$ \\
Crude lipid & 3.90 & $9.20 \pm 2.720$ & $8.35 \pm 0.225$ \\
Ash & 5.10 & $3.70 \pm 0.325$ & $3.70 \pm 0.825$ \\
Energy content $(\mathrm{kJ} / \mathrm{g})^{*}$ & 4.20 & $6.73 \pm 0.570$ & $6.46 \pm 0.175$ \\
\hline
\end{tabular}

Values are mean \pm SEM of two replicates. There were no significant differences between treatments $(\mathrm{p}<0.05)$.

* estimated energy values were calculated based on the conversion factors: protein $16.74 \mathrm{~kJ} / \mathrm{g}$ and lipid $37.67 \mathrm{~kJ} / \mathrm{g}$ (Yousif et al., 1996).

\section{Discussion}

Fingerlings averaging $3.38 \mathrm{~g}$ body weight stocked at $8 / \mathrm{m}^{3}$ and $12 / \mathrm{m}^{3}$ in sea cage nets attained by the end of the experimental period (213 days) a comparatively reasonable body size of over $180 \mathrm{~g}$. This size falls under the acceptable marketable limits in UAE (Anwahi et al., 1986). Compared to the results obtained by other workers for this species reared in floating net cages (Hortsmann, 1975; Tsueda et al., 1976; Tacon et al., 1990), the growth rates attained in the present study were superior. Beside the ideal culture conditions, this outstanding growth of the fish in the present study could also be attributed to the high protein content of the feed (52\%). Basayri and Tanaka (1988) reported that $S$. canaliculatus grew faster under diets containing 58\% crude protein than those fed lower levels. Parazo (1990) also demonstrated that diets containing high protein levels promoted good growth of $S$. guttatus. The growth of the fish was slow at the beginning of this study but accelerated in the later culture stages. The same phenomenon was reported by many researchers (Horstmann, 1975; Tahil, 1978). 
The results of the present study indicated that stocking density seems to have no negative effect on the growth of $S$. canalicultus. Most of the studies on stocking density of different cultured fish species suggested that crowding of fish usually leads to suppressed growth rates (Holm et al., 1990; Bjornsson, 1994; Irwin et al., 1999; Yousif, 2002). Our results may suggest that the highest stocking density applied in this study $\left(12 / \mathrm{m}^{3}\right)$ is still much below the maximum possible density and that there is a possibility of considering much higher stocking density. However, the results of the survival rates observed in this trial may discourage such trends. Though not significantly different $(\mathrm{p}<$ 0.05), the survival rate of the fish under higher stocking density was lower than that of the fish under the lower stocking density. In both treatments, most of the fish died during July and August where water temperature and salinity reached $35^{\circ} \mathrm{C}$ and $55 \mathrm{ppt}$, respectively. The dying fish were observed to completely stop feeding, swim near the water surface and their body coloration became very dark.

Although crowding has shown to interfere with feeding efficiency of many fish species (Beitinger, 1990; Montero et al., 1999; Yousif, 2004), our findings showed no such direct effect. The relatively increased FCR values obtained for both treatments are not surprising bearing in mind that the feed administered to the experimental fish was in fact shared by other wild fish fry freely entering the cages. The fry of at least five different fish species, Terapon theraps, Monodyctylus argenteus, Chanos chanos, Acanthopagrus latus, Sparus sarba and a wild small shrimp species Palaemon concinnus, were observed actively feeding with the experimental fish. Tacon et al. (1990) attributed the poor conversion ratios of $S$. canaliculatus raised in floating cages to the extraneous fish.

The initial and final carcass composition of the fish in both experimental groups showed almost similar values for crude protein but there were differences in moisture, lipid and ash. This is in accordance with the findings of Parazo et al. (1990) which showed that only these parameters were affected. The carcass moisture was inversely related to body fat content. This is in consistence with reports for $S$. canaliculatus and other farmed fishes (Patrichia et al., 1993; Yousif et al., 1994; Catacutan and Coloso, 1995; Yousif et al., 1996).

In conclusion, the results of this study further suggest the potential of $S$. canaliculatus for small-scale commercial farming in UAE. However, this potential remains hindered by the high mortalities during summer time. Most of the previous efforts to develop the culture of this species in UAE have concentrated on the culture methodology and nutrition studies (Yousif et al., 2005). More focus is needed to identify the causes of high mortalities during summer time and how to contain them.

\section{Acknowledgements}

The authors thank the entire staff of the Fish and Shrimp Farming Project at Abu Al Abyad Island for their collaboration and dedication. Special thanks to Ghaleb A. Alhadrami and Adil I. El-Awad of the College of Food and Agriculture, UAE University for their assistance with carcass analysis and to their colleague Dr. Salih A. Al-Shorepy for his assistance with statistical analysis.

The reference to any commercial product does not constitute endorsement of that product and does 
not imply approval to the exclusion of other products that may be suitable.

\section{References}

Al-Abdessalaam, T. Z. S. 1995. Marine species of the Sultanate of Oman. An identification guide. Ministry of Agriculture and Fisheries. Sultanate of Oman, 412p.

Anwahi, A. R., M. Ohashi and S. Marji. 1986. Feed made locally for rabbitfish, (Siganus canaliculatus). In: Hamdn, L.Y.; El-Nawawy, A. and Mameesh, M. (eds.). Proceedings of the First Conference on the Development of Food Industries in the Arab World. Kuwait, 13-16 October 1986. pp. 67-74.

AOAC. 1984. Official Methods for Anlysis of the Association of Official Analytical Chemists, 14th Edn. AOAC, Arligton, Virginia. 1141p.

Armando, A. J., M. Afonso and S. Luiz. 1999. Some aspects of of the biology of three fish species from the seagrass beds at Inhaca Island, Mozambique. Cybium 23 (4): 369376.

Basayri, A. and H. Tanaka. 1988. Studyon rearing of siganid fishes by commercial formula feed with different level of crude protein. Seafarming Workshop Report, INS/81/008/GEN/2 technical Report part 2, October 28 - November 1, 1985, Lampung, Indonesia. pp. 5862.

Beitinger, T. L. 1990. Behavioral reactions for the assessment of stress in fishes. Journal of Great Lakes Research 16: 495-528.
Beveridge, M. 1996. Cage aquaculture. Fishing New Books. London. 346p.

Bjornsson, B. 1994. Effects of stocking density on growth rate of halibut (Hippoglossus hippoglossus L.) reared in large circular tanks for three years. Aquaculture 123: 259270 .

Catacutan, M. R. and R. M. Coloso. 1995. Effect of dietary protein to energy ratios on growth, survival and body composition of juvenile Asian seabass, Lates calcarifer. Aquaculture 131: 125-133.

Holm, J. C., T. Refstie and S. B $\varnothing$. 1990. The effect of fish density and feeding regimes on individual growth rate and mortality rainbow trout (Oncorhynchus mykiss). Aquaculture 89: 225-232.

Horstmann, U. 1975. Some aspects of the mariculture of different siganid species in the Philippines. The Philippine Scientist 12: 5-20.

Irwin, S., J. O'Halloran and R. D. FitzGerald. 1999. Stocking density, growth and growth variation in juvenile turbot, Scophthalmus maximus (Rafinesque). Aquaculture 178: 77-88.

Lichatowich, T., S. Al-Thobaity, M. Arada and F. Bukhari. 1984. Growth of Siganus rivulatus reared in sea cages in the Red Sea. Aquaculture 40 (3): 273-275.

MAF (Ministry of Agriculture and Fisheries). 1984. Study on mariculture environment of Umm Al Quwain Lagoon and the experimental rearing of shrimp, rabbitfish and mullet. Technical Report No. 8. Department of 
Fisheries, United Arab Emirates. 72 p.

MAF (Ministry of Agriculture and Fisheries), 2003. Fishes. United Arab Emirates. Cultural Foundation Publications, Abu Dhabi. 255 p.

Montero, D., M. S. Izquierdo, L. Tort, L. Robaina and J. M. Vergara. 1999. High stocking density produces crowding stress altering some physiological and biochemical parameters in gilthead seabream, Sparus aurata, juveniles. Fish Physiology and Biochemistry 20: 53-60.

MRRC (Marine Resources Research Center). 1995. Technical reports on net cages. Ministry of Agriculture and Fisheries, Umm Al Qaiwain United Arab Emirates. 20p.

Parazo, M. M. 1990. Effect of dietary protein and energy level on growth, protein utilization and carcass composition of rabbitfish, Siganus guttatus. Aquaculture 86: 41-49.

Patricia, H. F., P. W. Woodie and I. J. S. Theodore. 1993. Effect of dietary menhaden oil on growth and muscle fatty acid composition of hybrid striped bass, Mornoe chrysps $\mathrm{x}$ Mornoe saxatilis. Aquaculture 116: 171-176.

SAS (Statistical Analysis Systems Institute). 1991. SAS/STAT User's Guide. Version 6.03. SAS Inst. Inc., Cary, NC.

Tacon, A. G. J., N. Rausin, M. Kadari and P. Cornelis. 1990. The food and feeding of of marine finfish in floating net cages at the National Seafarming Development Centre, Lampung, Indonesia: rabbitfish, Siganus canaliculatus (Park).
Aquaculture and Fisheries Management 21: 375-390.

Tahil, A. S. 1978. Experiment in rearing Siganus guttatus (Pisces: Osteichthyes, Siganidae) in a seacage and fishpens in the Philippines. The Philippine Scientist 15: 50-66.

Tsuda, R. T., P. G. Bryan, W. Fitzgerald and W. J. Tobias. 1976. Juvenile-adult rearing of Siganus (Pisces: Siganidae) in Guam. Univ. Guam Mar. Lab. Tech. Rep. 29: 1925.

Yousif, O. M., G. A. Alhadhrami and M. Pessaraki. 1994. Evaluation of dehydrated alfalfa and salt bush (Atriplex) leaves in diets for tilapia (Oreochromis aureus L.). Aquaculture 126: 341-346.

Yousif, O. M., M. F. Osman, A. A. Anwahi and T. Cherian. 1996. Optimum protein-to-energy ratio for two size groups of rabbitfish, Siganus canaliculatus (Park). Aquaculture Nutrition 2: 229-233.

Yousif, O. M. 2002. The effects of stocking density, water exchange rate, feeding frequency and grading on size hierarchy development in juvenile Nile tilapia, Oreochromis niloticus L.. Emir. J. Agric. Sci. 14: 45-53.

Yousif, O. M., M. F. Osman, A. R. Anwahi, M. A. Zarouni and T. Cherian. 2005. Growth response and carcass composition of rabbitfish, Siganus canaliculatus (Park) fed diets supplemented with dehydrated seaweed, Enteromorpha sp. Emir. J. Agric. Sci. 16(2): 18-26

Yousif, O. M. 2004. Apparent digestibility, growth performance 
Emir. J. Agric. Sci. 2005. 17 (2): 14-22

http://www.cfa.uaeu.ac.ae/Research/EJAS.htm

and feed utilization of juvenile Nile tilapia, Oreochromis niloticus L., as influenced by stocking density and feeding frequency. Emir. J. Agric. Sci. 16(2): 27-38. 